\title{
【論文】
}

\section{高層事務所ビルの避難訓練時の階段避難流動分析に基づく順次避難の改善 〜高層建築物からの全館避難を円滑化するリアルタイム技術の可能性〜}

\author{
Improvement of Phased Evacuation Scenario based on Analyses of Pedestrian Flow in
}

\author{
Stairwell during Drills in High-rise Office Building
}

- Possibility of real-time technique for facilitation of high-rise building evacuation -

\author{
朴聖經 (学生会員), 水野雅之 (正会員), 藤井皓介 (非会員)*, \\ 門倉博之(非会員)**，佐野友紀 (非会員)***，田中俊成(学生会員)，関澤愛 (非会員) \\ SeongKyung Park, Masayuki Mizuno, Kosuke Fujii*, \\ Hiroyuki Kadokura**, Tomonori Sano***, Toshinari Tanaka and Ai Sekizawa
}

\begin{abstract}
In Japan, a standard on the minimum capacity of escape staircases according to occupant load is not regulated except for some building uses. Therefore, staircases can't contain all occupants in an emergency case. Even though they attempt to evacuate building, most of them must wait in staircases and/or corridors for a long time, which must cause heavy congestion. Thereby, the phased-evacuation method has been recommended for preventing it, but there is no specific method or standard related to the strategic plan. In order to improve a sequential evacuation plan, evacuation drills were conducted at a high-rise office building in Tokyo, and year by year the scenarios of evacuation guidance were advanced a lot better. However, having several unexpected reasons or behaviors; not following broadcasting order, walking slow for chatting and having disability, some drills hadn't been carried out as predicted. The purpose of this study is to consider the real-time control method of changing the scenario for providing guidance flexibly in a sequential evacuation using security device such as attendance management system and security cameras in the future.
\end{abstract}

Key Words

Phased evacuation, High-rise building, Evacuation drill, Evacuation scenario, Real-time control

\footnotetext{
2020 年 01 月 23 日受付

2020 年 09 月 04 日掲載決定

東京理科大学大学院 理工学研究科

干278-8510 千葉県野田市山崎 2641

* 消防庁消防研究センター

干182-8508 東京都調布市深大寺東町 4-35-3

** 東北学院大学工学部

于985-8537 多賀城市中央一丁目 13-1

*** 早稲田大学人間科学学術院

干359-1192 埼玉県所沢三ヶ島 2-579-15

Tokyo University of Science

2641, Yamazaki, Noda, Chiba, 278-8510 Japan

* National Research Institute of Fire and Disaster, 4-35-3, Jindaiji Higashimachi, Chofu, Tokyo, 182-0012 Japan

** Tohoku Gakuin University 1-13-1, Chuo, Tagajo, Miyagi, 985-8537 Japan

*** Waseda University, 2-579-15, Mikajima, Tokorozawa,
}

1. はじめに

\section{1 研究背景}

日本の建築物は, 一部の用途を除き, 建物の収容人数に応じ て避難階段の最低容量に関する基準を設けていないため, 高層 建築物では階段が負担寸る人数が大きい場合がある. 例えばア 刚カでは, 建築物の収容人数の規模に応じて階段系統数を増 や寸基準が規定されている 1)。一方，日本では階段までの歩行 距離を制限することで, 階数とは無関係に平面規模の増大に応 じて階段数を増や寸基準が規定されている 2).例えば火災によっ て全館一斉避難の指示が出された場合,階段に避難者が集中し， また階段につながる廊下でも長蛇の列を形成することが予想され る.これらに加えて, 煙の侵入や人がパニックを起こすと群集災 害や体調不良(熱中症等)を引き起こす可能性もある. また, 火災 では万が一竪穴を介した煙流動が起こると，上層階の在館者が 
煙に曝される恐れがある. 東日本大震災の際には東京都内のあ る超高層オフィスビルで自動火災報知器が作動し, 放送により全 館一斉避難が指示された. 結果的に局所的な小火であったもの の階段では大混雑を引き起こし, 全館避難の流動制御の重要性 を露呈した.こうしたことを踏まえ, 段階的に在館者を避難させる 順次避難計画を推奨する必要があると考える．しかしながら，順 次避難計画を立てる方法については, 各階の在館者人数や出火 階の変化により避難シナリオを適宜変える必要があると予想され るが, その具体的な方法やそれに関連する基準はない.

そこで, 我々の研究グループでは, 建物火災時における順次 避難計画を立案するための手法を開発することを目標として, 高 層事務所ビルにおける全館避難訓練に順次避難計画を取り入れ, その避難流動を調査する研究を継続的に実施してきた ${ }^{3), 4)}$. 階段 を降下寸る避難流動量の把握や階段室に入る流れと階段を降下 する流れとの合流比等を分析してきた4).このほか, 階段を降下し て避難する避難流動を調査した既往の研究には, 本研究と同じ ように避難訓練における避難者の流れを観察したものと, 実験的 研究として避難者役の被験者が階段を降下する状態を観察した ものがある. 前者は, 計算モデルを提案し, その結果について避 難訓練における避難流動の再現性を確認する内容である ${ }^{5)}$. 後 者は, 前述した階段降下と階段流入との合流比を調查した研究 が幾つかあり,一般的な構造の階段において概ね等しい流量比 で合流したこと ${ }^{6}$ や階段扉の配置や階段降下の避難者の列数を 変えることで合流比や流動量が変わる結果を得ている 7). これら の研究成果の順次避難計画への活用については, 実際の避難 流動にどのように影響を及ぼすかを考慮しながら検討する必要が ある.

こうした避難流動の調査は, これまでビデオカメラで録画した映 像に基づいて分析されてきたが, その動画を機械学習させて画 像認識により人の動きを把握する方法の開発も進んでおり, 我々 の研究グループでも取り組んできた ${ }^{8)}$. 今後, こうした画像認識技 術をシミュレーションや計算プログラム等と IoT 技術によってリア ルタイムで連動させることで，順次避難計画を最適化する技術 を確立させられると考えており, その方向性を本稿で取り上げる. なお, リアルタイムに情報を集積することで, 各階からの避難者数 の増減, 階段室に流入するタイミングの遅れや早まり, 高齢や傷 病等により移動速度が遅い人を含むことによる避難流動の低下 などを把握し, 逐次予測計算により避難シナリオを修正でき, そ れをフェイズ毎の避難開始指示を出す放送のタイミング調整に反 映させられる. 本稿において, フェイズとは, 同時に避難指示を受 ける階等のグループを表す.また, 事前の予測ばかりでなくリアル タイムによる状況把握を反映させるシステムの必要性を考える端 緒となった, 避難訓練において確認された様々な予想外の行動 例についても報告する.

\section{2 研究目的}

本稿では,これまでに実施してきたある高層事務所ビルでの全 館避難訓練の調査結果を示し, 順次避難計画における避難開始 シナリオの最適化プロセスを報告する. また, 本研究では, 階段 内の避難流動に着目して調查分析し, 同調査によって確認され
た様々な予想外の避難行動について, より適切な順次避難計画 を立案する視点から考察する. 加えて, 将来において開発が期 待される防犯カメラなどのセキュリティー機器などを活用した順次 避難計画における避難開始シナリオのリアルタイム制御手法につ いて考察する.

なお, 本稿におけるシナリオの最適化とは, 階段内で避難者が 帯留する時間を短くすること, 及び避難階である 1 階での階段か らの避難者の流出が途切れたり低下しないことを対象とする.

\section{2. 避難訓練調查}

\section{1 避難訓練の調查対象建物の概要}

調査建物は, 東京都内の某企業の本社ビルであり, 全館避難 訓練の調査協力を得ることができた. 建物は, 地下 3 階, 地上 25 階建てであり, 9 階以下の階は機械室や会議室, 応接室, 社員食 堂などが入り, 10 階以上に事務室が存在する. そのため, 10 階 以上に主に避難者が存在し, 避難訓練参加者数も異なるため, 各階からの避難者数がばらついた. なお, 階段室の寸法は, 階 高が $3.8 \mathrm{~m}$ の事務室用途の基準階である 7〜25 階の代表值では, 階段の䟣上げが $0.173 \mathrm{~m}$, 踏面が $0.28 \mathrm{~m}$, 幅が $1.2 \mathrm{~m}$ で, 階段の 扉幅が $1 \mathrm{~m}$ であった. また, Fig. 1 に示した通り, 避難階段はコア の南北両端に 2 力所設置されていた.

火災が発生した場合,一般的に, 2 つ階段のうち各在館者か ら近い方一避難するが，避難訓練では放送での指示により片方 の階段のみから避難した.これにより 2 つの階段を使用した場合 よりも一部の在館者は長い距離を移動して階段に到達するため, 階段への到着時間分布のばらつきが大きくなる可能性がある.し かし, 実際には2つの廊下から 1 つ階段に避難者が集まるため, 避難者は階段出口から廊下にかけて列をなして待つ状況が生じ る. 今回の避難訓練でもほとんどの階で階段への出口前で待つ 状態が生じたため, 階段までの移動距離が延びたことによる階段 到着のばらつきが大きくなったことの影響はなかったといえる.

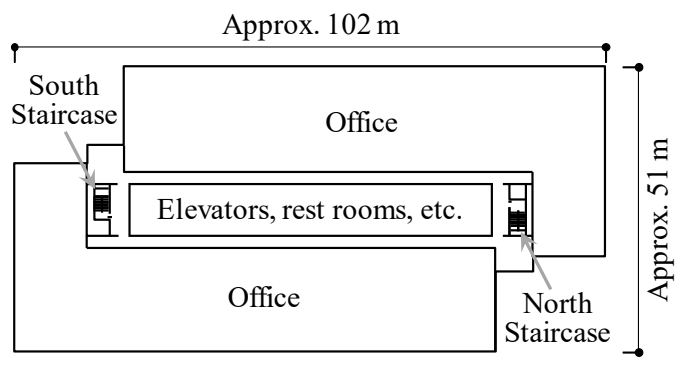

Fig. 1 Floor plan of typical office floor

\section{2 避難訓練の撮影エリア}

本研究では, 避難訓練時の階段内における避難者の流動状 況を, 各階から階段踊り場に流入する流動状況も含めて撮影す るために, 全ての階の踊り場 (階段扉あり)をビデオカメラで撮影し た. また, 中間踊り場(階段扉なし)や段部も一部の階について撮 影した. 動画は, プライバシーに配慮し, 個人を特定しにくいよう に上方から撮影され, さらに解像度を低く変換した. また, 本調査 の実施は事前に周知された上で社員は避難訓練に参加した. 
Fig. 2 の左に示した踊り場 (Landing)においては, 上階から下り てきた避難者が段部 (A flight of stairs)から踊り場に入る境界線 (緑), その階の避難者が階段外から踊り場に入る境界線 (青), そしてこれらの避難者が踊り場から段部に出る境界線(赤)を設定 し, それらの境界線を通過する避難者の人数を 1 秒間隔で時間 に紐付けてカウントした. なお, 避難者が階段室から出ていく 1 階 では, 青の境界線において踊り場から階段外に出る境界線の通 過人数をカウントした.

\section{3 避難流動のデータ化}

前項に記載した境界線の通過人数を時刻に紐付けてカウント することにより, 各時刻の避難流動量を把握することができる. た だし, 1 秒毎にカウントしているものの, 1 秒間に通過する人数は 0 人, 1 人, 2 人の 3 パターンで, それが変動するため, 単に人が 通過しているか否かがわかるデータにしかならない. そこで, 既発 表の論文3)を参考に 15 秒毎に区切った上で, その間の通過人数 を 15 秒で除して単位時間当たりの流動量 $[\mathrm{p} / \mathrm{s}]$ を算定した. なお, 1 階層を下りるのに速い人でも 15 秒程度を要したため, 各階を順 に通過する状況を最低限把握できるように 15 秒間隔を採用した. なお, 前述の境界毎に次の通り名称を設定した.

•緑の境界線：Tread to Landing ( $\mathrm{T}$ to $\mathrm{L}$ )

•青の境界線：Floor to Landing (F to L)

•赤の境界線: Landing to Tread ( $\mathrm{L}$ to $\mathrm{T}$ )

\section{4 トレーサーによる避難流動の把握}

各階の避難群集の先頭集団にトレーサーとして調査員を一緒 に避難させ，階段に入ってから各階の踊り場に到着する毎にス卜 ップウオッチを用いてラップを刻み, 1 階層を降下する時間を測定 した.これを時刻と紐付けすることにより，任意の階からの避難群 集が階段に入った後, スムースに階段を降下できたか, ある階を 降下するのに長時間を要したかを把握することを試みた。

なお, 一部の階には, 先頭集団だけでなく, その階の最後尾や 中間と思われる避難者に付くトレーサーも配置した.

\section{5 順次避難シナリオの設定とその改善}

避難訓練は 2014 年まで特別避難階段 2 つを使用していたが, 参加者数の減少を受けて, 2015 年に実施した避難訓練を皮切り に, 片方の階段のみを避難訓練に使用し, 毎年試行錯誤しなが ら順次避難シナリオを設定し避難訓練を実施してきた. 本稿では 2015２018 年の調査デー夕を分析した. なお, 調査対象建物の 収容人員は 6000 人規模であるが, 実在館者数は 4000 人規模で あったため, 実際の全館避難では 1 階段を大凡 2000 人が通過す る見込みである.ただし, Fig. 1 のように平面計画は点対称である が, 各階の在館者分布によって両階段の使用人数は異なるため 増減が見込まれる. 調查した避難訓練の参加者数は, 後述の通 り約 900〜 1600 人であった.

2015 年の避難訓練では, Fig. 3 に示したシナリオで避難開始 の指示を防災センターから館内放送を用いて実施した. 第 1 フェ イズと第 2 フェイズとの間は 2 分, 第 2 フェイズと第 3 フェイズとの 間は 5 分のインターバルを設けた. 前者の 2 分は, 次のような理 由で設定された. 一つは, 第 1 フェイズに対する避難指示として, 4 階で火災が発生して初期消火に失敗したために 4〜6階の在館
者に避難を指示する内容の放送を日本語と英語で 2 回繰り返し て行うが, これに 2 分弱を要したためである. また, 訓練では 4〜6 階から避難する在館者はほとんどいないため, 3 階層からの避難 に要する時間が長くなることを考慮する必要がなかった. 第 2 フェ イズは, 第 1 フェイズのすぐ上の火災による延焼リスクが高い 7〜 12 階の 6 階層と, 建物内の煙污染のリスクが高い最上階を含む 21〜25 階の 5 階層とした. 7〜 12 階は実質 10～12 階の 3 階層か ら多くの在館者が避難した. また, 21〜25 階は一部の階から多く の在館者が避難したが，他はそれほじ多くない. 第 3 フェイズの 指示は第 2 フェイズから 5 分遅れとしたが, これが結果的に十分 なインターバルでなかったために第 2 フェイズの避難者との合流 による混雑を生じたことと，13～20 階の 8 階層が同時避難したこと で同一フェイズ内での合流による混雑も生じた.

この 2015 年の避難訓練の結果を受けて, 2016 年以降は第 3 フェイズの 8 階層を 2 分割して, 17〜20 階の 4 階層を第 3 フェイ ズ, 13〜16 階の 4 階層を第 4 フェイズとし, 第 2 と第 3 , 第 3 と第 4 のフェイズ間のインターバルを調整した(Fig. 4). 結果しして,

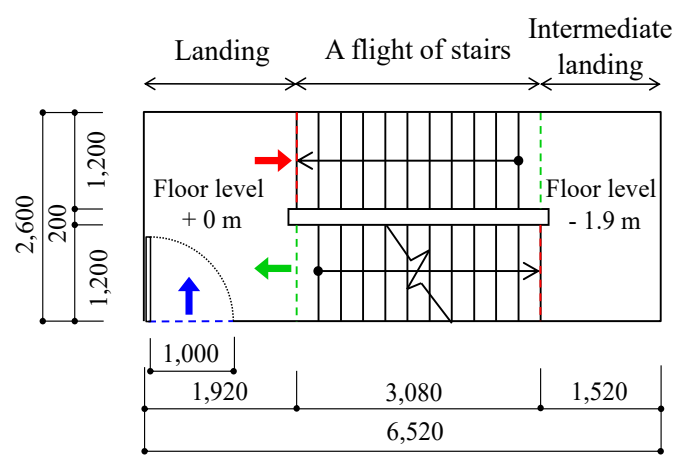

Fig. 2 Shot areas in staircase

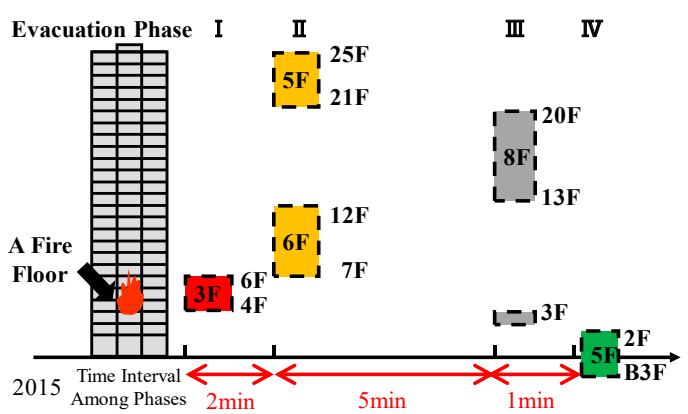

Fig. 3 Evacuation scenario in 2015 drill

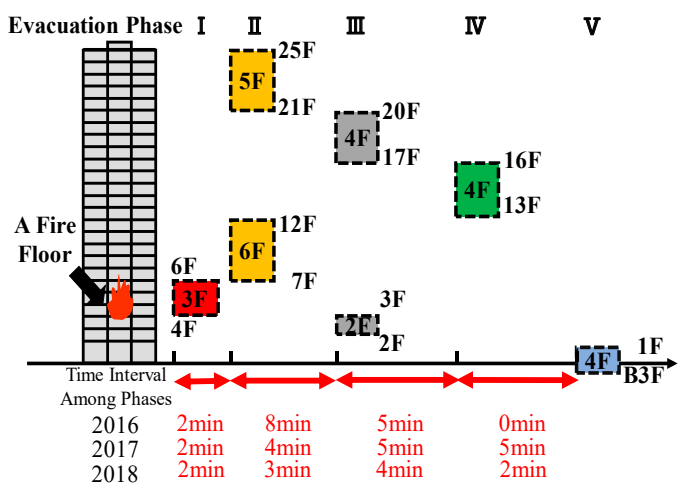

Fig. 4 Evacuation scenarios in 2016-2018 drills 
2016 年はそれらのインターバルを長く取り過ぎたために, 階段 1 階出口からの避難流動が途切れる現象が発生した.これを踏ま えて, 避難効率を高めて避難時間を短縮するためにシナリオを改 善した. 実際には避難訓練の参加者数が年々減少したことも影 響したが, 2018 年は目立った混雑もなく, 1 階出口で避難流動が 途切れることもなく成功した一例といえる。

\section{6 画像認識プログラム}

撮影した映像は 1 秒間につき 30 フレイムの画像で構成されて おり, その動画を機械学習によって人の頭 (頭髪の色等, ヘルメ ッ小の着用等の条件を学習させた) を認識し, 階段踊り場での移 動軌跡を把握できるプログラムを導入した (Fig. 5). 本プログラム では, 避難者が階段踊り場を通過する様子を撮影した映像から 避難者の流動状態を把握するものであるが, 避難者の角度や大 きさが異なるため, 画像処理を使った形状の一致具合を使って物 体を捉えることが難しいと判断し，物体認識のアルゴリズムとして ディープラーニングを使った物体認識 SSD (Single Shot MultiBox Detector)を採用した ${ }^{8)}$. SSD は, オープンソース機械学習プラット フォームである TensorFlow + Keras を実装し, 頭髪の色や量が異 なる人々、ヘルメットをかぶった人々の頭部を認識可能とした 9).

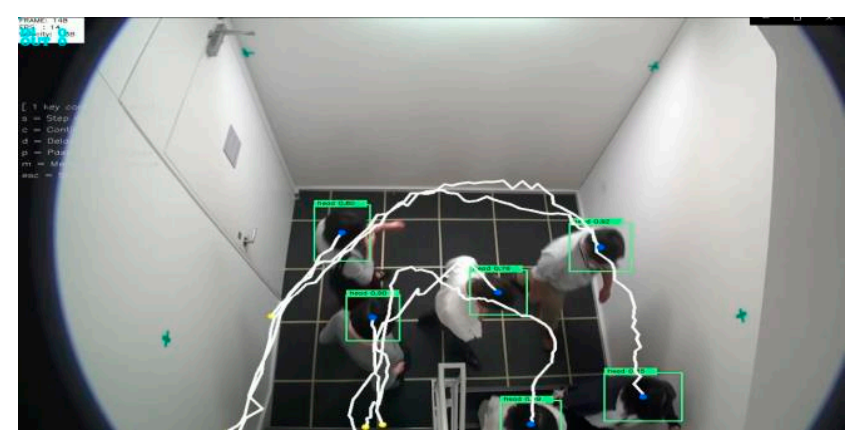

Fig. 5 Evacuation flow analysis through vision recognition

\section{3. 調查結果 \\ 3.1 トレーサーの階段降下履歴の分析}

Fig. 6 と Fig. 7 は, それぞれ 2015 年と 2018 年の避難訓練にお いてトレーサーが階段内を降下寸る状況を表現したものである. 右肩下がりのグラフが急な傾斜は途中で立ち止まったり, 他の避 難者が階段に入ることによる合流の影響を受けずスムースに階段 を降下している様子(1 階層の降下が 20 秒程度)を表している. 傾斜が緩やかになっているところは, 次の下の階に到達するまで に長時間を要したことを表しており, 滞留が発生した箇所と見な すことができる. 例えば, Fig. 6 の 420秒に灰色の点線が引いてあ り, これは第 3 フェイズの避難開始の放送開始時点を表している が, その頃に第 2 フェイズの 21〜25階からの避難者が第 2 フェイ ズの 7〜12 階からの避難者(正確には 12 階の踊り場での滞留) に追いついたために滞留したことがわかる.特に 10〜12 階の連 続する 3 階層は避難者が多かったため, グラフにそれらの階から 階段室に列をなして避難した時間帯を表示したように 12 階では 長時間の滞留が発生した. 例えば, 第 2 フェイズの上層部から最 初に階段を下りてきた 21 階のトレーサー(21F-1) は13 階まで急な
傾きで, 13 階から 12 階, 12 階から 11 階に到達する部分では長 時間要したため傾きが緩やかで, 11 階通過以降は再び急な傾き となった. そして, その滞留が生じた場所は第2フェイズの $21 〜 25$ 階から遅れて階段に入ったトレーサーほど上の階になっていたこ とがわかる.さらに, 第 3 フェイズの $13 \sim 20$ 階からの避難者は, そ れらの階における階段室が第 2 フェイズの 21〜25 階からの避難 者によってある程度占有されていたために, 階段に入った後すぐ に滞留することを余儀なくされた. すなわち, 第 3 フェイズの 13〜 20 階のトレーサーはそれぞれ階段室に入る時間に差があるが, Fig. 6 に描かれたグラフの始点から右肩下がりの傾斜が緩やかに 描かれ, その後傾斜が急になりスムースに避難した状態になる. そして, スムースに避難し始めた時間は, 大凡 13 階で 650 秒, 15 階で 850 秒, 16 階で 900 秒, 18 階で 1000 秒, 19 階で 1100 秒と なり，上層階ほど遅くなった。

これに対して, Fig. 7 のグラフでは, ほとんどのグラフが右肩下 がりの傾斜が急な状態のグラフとなっており,トレーサーが階段室 に入った後スムースに階段を降下できたことがわかる.グラフに表 示した 10〜12 階から階段室に列をなして避難した時間帯は, 特 に 12 階で大きく短縮され, 第 2 フェイズの 21〜25 階から避難し たトレーサーへの影響がわずかにあったものの, 階段室内で停 滞することなく避難した。

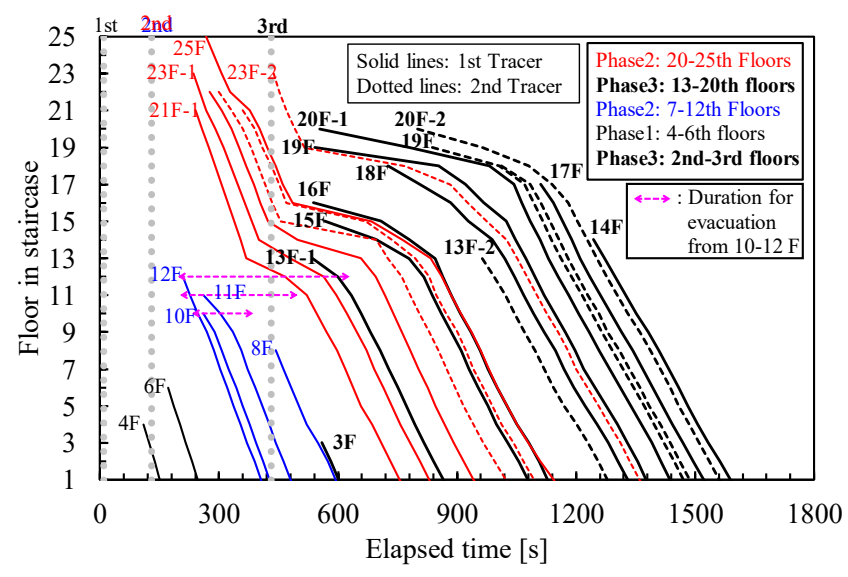

Fig. 6 Tracers' descending on stairs with time in 2015 drill

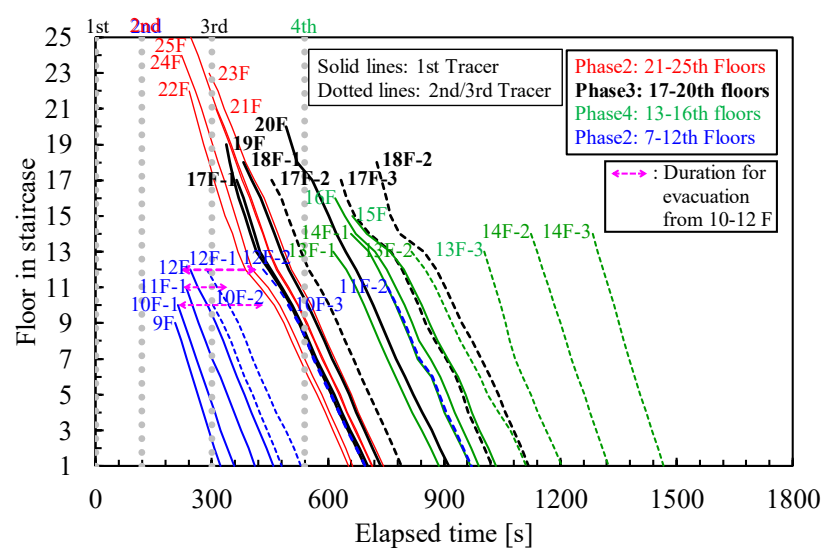

Fig. 7 Tracers' descending on stairs with time in 2018 drill 


\section{2 階段室の 1 階出口からの避難流動状況の分析}

2015 年から 2018 年までの避難訓練における階段 1 階出口から の避難者の累積人数を Fig. 8 に示寸. 同出口からの避難者の累 積人数によれば, 2015 年の参加者は 1596 人であったが, 2016 年は 1111 人, 2017 年は 1003 人, そして 2018 年は 939 人と減少 した.

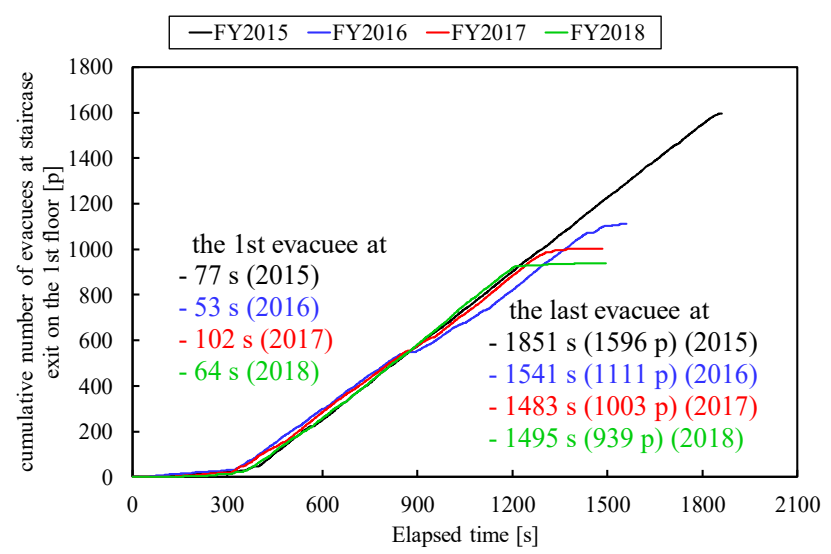

Fig. 8 Cumulative number of evacuees at staircase exit on $1 \mathrm{~F}$

階段 1 階出口からの避難者の累積人数のグラフは, 実施年に よって異なるが, どの年も概ね 300 秒を過ぎた辺りから避難者が 継続的に 1 階出口から避難し, 累積人数が増大し始めた. 第 1 フ エイズの避難者はほとんどいなかったため, グラフは 300 秒過ぎま で横ばいだったが, 第2フェイズの避難者が 1 階出口に到達し始 めて累積人数が増大し始めた. 4 本のグラフの内, 2015 年(黒)之 2018 年 (緑)のグラフは累積人数が継続的に増大しているが 2016 年(青)と 2017 年(赤)は一時的にグラフが横ばいになり, 増大傾 向が緩やかになった時間帯 (概ね 900 秒前後)が存在した. これ は, 1 階からの避難者の流出が途切れ途切れとなったことに起因 する. また, グラフの最後は 2016〜2018 年では累積人数の増大 傾向が緩やかになったのは, 後から遅れて階段に入ってきた 人々がまばらに存在し避難したためである.

階段 1 階出口からの避難者の流動量 $[\mathrm{p} / \mathrm{s}]$ の推移をFig. 9 に示 した. 流動量が一時的に減少した原因は次の通りである. 2015 年 (黒)では, 555 秒で $0.33 \mathrm{p} / \mathrm{s}$ となり, これは第 3 フェイズの 3 階か ら避難した視覚障害者とその介助者が主に第2フェイズの避難群 集に合流し, 彼らの前方に隙間が生じたためであった. 2016 年 (青)では, 900 秒で $0 \mathrm{p} / \mathrm{s}$ となり, これは第 2 フェイズの上層部から 避難した後方の避難群集と第 3 フェイズの避難群集が階段で交 わらず, その間に避難者が存在しない隙間が生じたためであった. また, 1065 秒で $0.47 \mathrm{p} / \mathrm{s}$ となったのは, 第 2 フェイズの一部の避難 者が遅れて避難(第2フェイズの避難指示から 8 分以上遅れて 24 階から避難)して第 3 フェイズの 17 階からの避難群集に合流し, 前者の階段降下が遅かった（横に並んで会話しながらの階段降 下が原因）ために前を行く人との間隔が開いたためであった. 1140 秒で $0.6 \mathrm{p} / \mathrm{s}$ となったのも, 第 3 フェイズの後方の避難群集の ある避難者 (17 階から避難. 第 4 フェイズの前方の避難群集がこ の後ろにつながる)の階段降下が遅かった(他者との会話が原
因)ために前を行く人との間隔が開いたために流動量が一時低 下した. また, 2017 年(赤)では, 885 秒で $0.53 \mathrm{p} / \mathrm{s}$ に一時低下し たのは第 2 フェイズの上層部からの避難群集に対して, 第 3 フェ イズの避難群集が交わったところで避難者数が減少し密度が低 下したためであった. 960 秒で $0.6 \mathrm{p} / \mathrm{s}$ に一時低下したのは, 第 3 フェイズの一部の避難者が遅れて避難(第 3 フェイズの避難指示 から 5 分程度遅れて 18 階から避難)し, 彼らの後方に続いて第 4 フェイズの避難群集が避難したが, 彼らの前方に隙間が生じたた めであった.

これらの流動量が一時的に低下した現象を整理すると, 2016 年と 2017 年は第 2 フェイズと第 3 フェイズの避難群集との間に隙 間が生じたためであり, 避難開始指示のインターバルを縮めたこ とで 2018 年には解決された. その他は, 一部の避難者の階段降 下が遅かったために前方に隙閒が生じたためであった. また, 2015 年と 2018 年は継続的に避難者が階段 1 階出口から流出し た時間帯では $0.8 \mathrm{p} / \mathrm{s}$ 未満に流動量が低下しなかった.

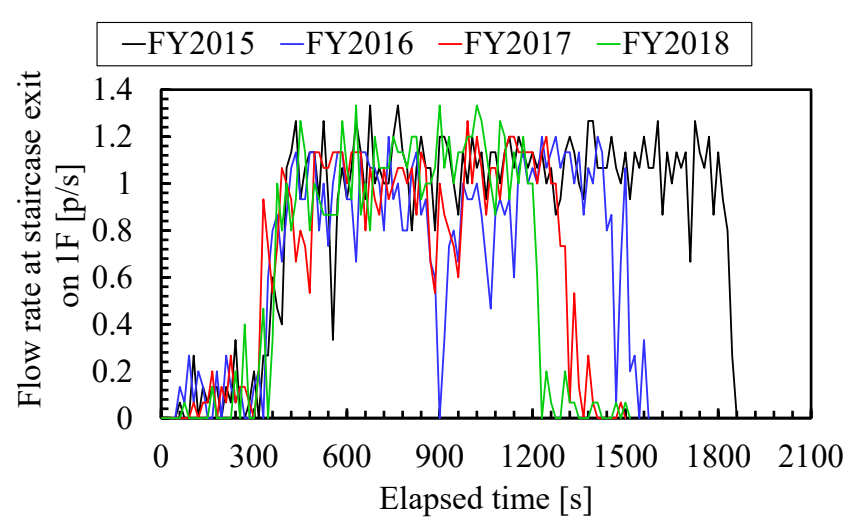

Fig. 9 Flow rate at staircase exit on $1^{\text {st }}$ floor

\section{3 階段の途中階での流動量の分析}

3.1 節で述べたとおり, 2015 年は第 3 フェイズの 13〜20 階から の避難者は階段室に入ったところで滞留し, スムースに階段を下 り始めるまで上階ほど時間を要したことが,トレーサーの階段降下 履歴から分かった. そして, この状況を改善すべくフェイズ分けを 2016 年以降に第 3 フェイズ 17〜20 階, 第 4 フェイズ 13〜16 階 に変更した. その効果を階段内の避難流動状態から分析するた め, その代表階しして 13 階と 17 階 (2016 年以降の第 3 と第 4 フ エイズの最下階)を選定し, 上階から踊り場に入る流動量 ( $\mathrm{T}$ to $\mathrm{L}$ ) をグラフに示した(Fig. 10, Fig. 11).

2015 年は, 13 階の流動量が, 第 3 フェイズの放送前の 390 秒 で第 2 フェイズの上層部からの避難者が到達したことにより 0.93 $\mathrm{p} / \mathrm{s}$ に一時的に上昇した後, 第 2 フェイズの下層部からの避難に より 12 階で滞留が生じていたため低下した. その後, 第 3 フェイ ズの放送以降に 11 階から階段一の避難終了が 500 秒, 12 階か らが 620 秒, そして 13 階からが 960 秒になり, それぞれにタイムラ グを経て 13 階の上階から踊り場への流動量 (13F T to L) が段階 的に上昇し, 1020 秒以降に概ね定常状態で $1.2 \mathrm{p} / \mathrm{s}$ となり, そして 1500 秒以降に通過する避難者が減り, 流動量も小さくなった. 17 
階も同様に, 第 3 フェイズの放送前に第 2 フェイズの上層部から の避難者の通過により流動量が上昇し, そして第 3 フェイズの放 送が開始された後, 第 2 フェイズの上層部からの避難者が通過し 滞留したことで流動量が $0 \mathrm{p} / \mathrm{s}$ になった. その後, 第3フェイズから の避難者が階段に避難し始めたことで 750 秒に $0.87 \mathrm{p} / \mathrm{s}$ に回復し た後, 13 階から階段に避難している状態で 12 階以下及び 14〜 17 階では階段への避難は終了していたため, 流動量は 13 階と 同等に回復しているものの, 13 階から 17 階までの階段内の避難 者が断続的に滞留して動いたり止まったりを繰り返したために上 昇と低下の繰り返しが続き, 避難者が通過し終えたことで 1215 秒 に流動量が $0 \mathrm{p} / \mathrm{s}$ になった.

一方, 2018 年は, 第 3 フェイズの放送を早めたことでその前後 での流動量の低下は, 13 階及び 17 階において見られなかった. そして, その流動量は一時的に低下するような挙動を示さず, 第 2フェイズの上層部からの避難者の到達に伴い山なりを描くように 上昇してから, 17 階は第3フェイズの避難者の通過終了, 13 階は 第 4 フェイズの避難者も通過終了を経て低下した.

2015 年と 2018 年を比較すると, 通過した避難者数の違いがあ ったことは確かであるが, 2015 年は流動量が上昇した後に一時 的に低下したこと，また 17 階では流動量が回復した際に上昇と低 下を繰り返したことが, 2018 年の流動量の変化と明確に異なって いた。

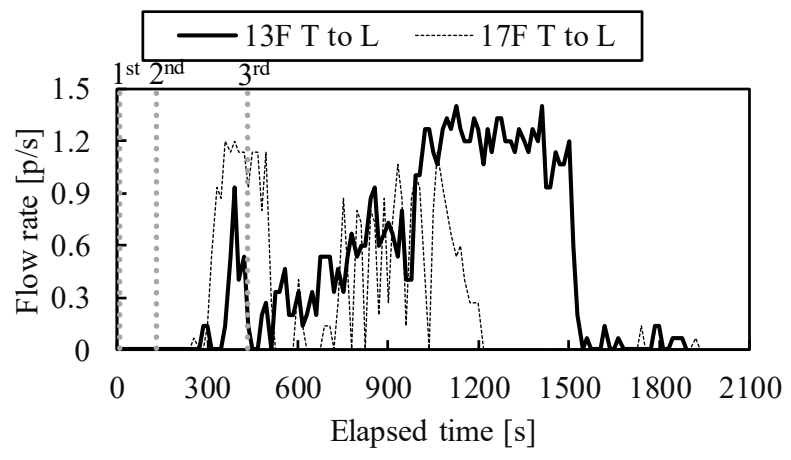

Fig. 10 Flow Rate of $\mathrm{T}$ to $\mathrm{L}$ on $13 \mathrm{~F}$ and $17 \mathrm{~F}$ in 2015 drill

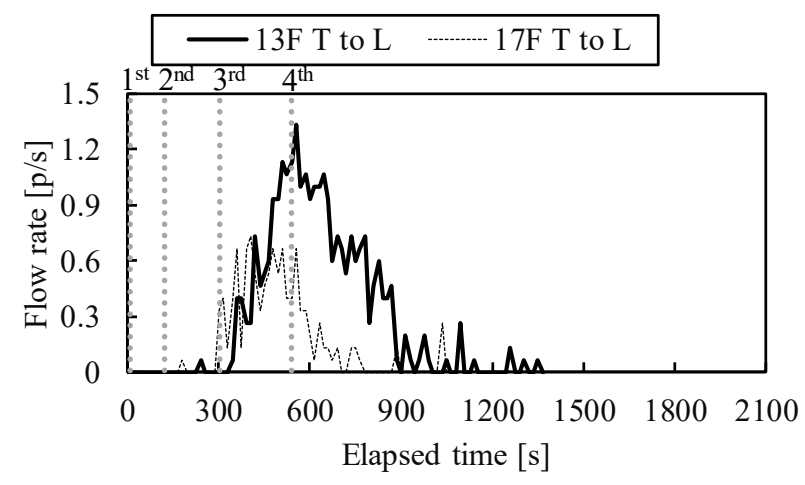

Fig. 11 Flow Rate of $\mathrm{T}$ to $\mathrm{L}$ on $13 \mathrm{~F}$ and $17 \mathrm{~F}$ in 2018 drill

\section{4. 調査結果の考察と議論}

\section{1 避難シナリオの変更による階段内の混雑の改善}

Fig. 6 より, 2015 年の避難訓練では, 第 2 フェイズの上層階 21 〜25 階から避難した人々は, 第 2 フェイズの低層階 7〜12 階(実
質 10〜12 階)からの避難者に合流し, しかも遅れて階段を下りて きた人は階段内で滞留した時間が長くなった. 例えば, 25 階から 避難した卜レーサーは 16 階から 15 階に下りるまで概ね 200 秒を 要した. 23 階から避難した 2 番目のトレーサー $(23 \mathrm{~F}-2)$ は, 19 階 から 18 階に下りるのに 254 秒を要した. 一方, 第 3 フェイズの 13 〜20 階からの避難については, 階段に入った当初から第2フェイ ズの避難者が第 3 フェイズの階の階段室内に滞留していたため, 早期に階段に入れたとしても, 滞留している階段の下の方の階か ら順に滞留が解消されるまで待つ必要があった. 例えば, 20 階か ら避難した 1 人目のトレーサー $(20 \mathrm{~F}-1)$ は, 19 階に下りるまで 225 秒を要した.また, 18 階から避難したトレーサーは, 階段入室が 725 秒で第 3 フェイズの避難指示放送から約 5 分を要しており, 他の階と比較して 3 分程度遅れた. さらに 14 階や 17 階に至って は, 避難し始めた頃に階段内が混雑していたため, 階段扉を開 いてから階段に進入するのを諦め, 混雑が解消されるまで待った。 そのために, それぞれ 1243 秒, 1111 秒に階段に入室した. 第 3 フェイズの放送開始からぞれぞれ 823 秒, 691 秒遅れての階段入 室であった。階段内のみならず廊下において列をなして待機せ ざるを得ない状況が生じたと考えられる. したがって, 同一フェイ ズで上層部と下層部に分けた場合, 上層部からの避難者が下層 部の階への到達も考慮し, また上層部と下層部の間の階から次 のフェイズで避難させる場合には，その階数や避難開始のタイミ ングを, それらの合流や滞留時間の抑制を考慮して設定する必 要がある.

また，階段上部からと各階からの避難群集が合流寸ると，それ ぞれの流動量が半減し，その比率は 1 対 1 に分配されたことが既 調査で報告された ${ }^{10)}$. 本調査においても, 例えば Fig. 10 に示し た 13 階の踊り場に下りてくる流動量は, 960 秒に 13 階から階段 への避難が終了するまでは 780 秒からの時間帯では平均で 0.6 $\mathrm{p} / \mathrm{s}$ を上回る程度であったが，1020 秒以降では $1.2 \mathrm{p} / \mathrm{s}$ を上回る程 度となり, 13 階からの避難群集の合流により半減されていた. そし て, 2 つの階で合流が生じ, その間の階段が高密度状態で満たさ れると, 合流のあった 2 つの階のうち下の階では流動量が半減さ れて $1 / 2$ となり, 上の階ではさらに流動量が半減されて $1 / 4$ となる. さらに 3 つの階で合流が生じ, その間の階段が高密度状態となる と, 3 つの合流のうち最も上の階では流動量が $1 / 8$ に低下する.

Fig. 10 において 300 秒頃に 17 階を通過した第 2 フェイズの上層 部からの避難者が 360 秒頃に 13 階に到達したことで流動量が上 昇したが, Fig. 6 に示したように同時刻には 10〜12 階から避難し ており 3 つの階で合流が生じたため 12 階の踊り場への避難流動 が理論的に $1 / 8$ に低下し, 12 階から 13 階までも高密度状態とな った.これにより 13 階の流動量は一時的に 0 まで低下し, 動画を 確認すると実質的に長い間止まっており, 滞留状態を引き起こし た.したがって, 3 つの階で合流が起こり, かつその間の階段が高 密度となる時間を抑制することにより避難者が停止するような帯留 時間を抑制することができると考える.

こうした状況を避難フェイズ分けとシナリオを改善することで解 消されたことは明らかであり, 2018 年の避難シナリオは適切なも のであったといえる. ただし, 単に滞留の発生を抑制することだけ 
を考慮すると, 階段の避難流動の途切れや低下が生じるため, そ の分だけ全体の避難完了時間が遅れることになる. 例えば, 2016 年と 2017 年の避難訓練がそれに相当した. したがって, 避難者 を合流させてある程度の滞留を引き起こすことを許容しつつも, 極端に長時間に及ぶ滞留を生じないように順次避難計画を立案 することが肝要である. また, フェイズ間の避難指示のインターバ ルの影響ではなく, 一部の避難者の階段降下が遅かったために 彼らの前方に隙間が生じ流動量が低下した現象は, 避難中の会 話を行わないなど避難者の意識改善を図る必要がある一方, 身 体的な能力に起因寸るものは不可避であるため, そうした影響度 を評価することも課題といえる.

\section{2 順次避難(Phased Evacuation)を実施する上での課題}

順次避難に関する記述としてロンドン消防が発行した政策 （1991 年発行. 2015 年確認.）においては, 出火階とその直上階 をまず避難させ, 続いてその上階に向かって 2 階層ずつ避難さ せ, 最上階まで避難させた後に出火直下階から下階に 2 階層ず つ避難させる方針が示された ${ }^{11}$. 一方で, 全館避難を前提とせ ず，火災ゾーンと称する出火階を含む火災の影響範囲を設定し， 延焼や煙拡大もそのゾーンの境界を超えないように対策を施し， その上で火災ゾーンの範囲の在館者に火災ゾーン外に避難を指 示寸る考え方も提案された ${ }^{12}$. また, 避難シミュレーションソフトを 用いた検討では, 出火階を優先させて, 直上階は 20 秒遅れ, そ の上階は 40 秒遅れ, さらにその上階と火災階の直下階は 120 秒 遅れ，さらに上階と下階を交互あるいは同時に避難させるように アルゴリズムを提案した研究成果もあった ${ }^{13)}$.このように順次避難 計画に関しては統一的な手法が周知されている訳ではなく, また そのシナリオの計画法も同様に確立されていない. 本研究にお いては, 2.5 節に記載の通り, 同一フェイズの階からの階段への 避難流動の合流によって過度な滞留が生じないように配慮したフ ェイズ分けを採用し，さらに火災による延焼リスクと煙伝播りスクに 配慮した避難シナリオを計画した. ロンドン消防は, 火災階から段 階的に上階に避難開始階を移行させる方針を打ち出しているが, 万が一煙が壁なごの隙間から㹂穴空間に進入すれば, 浮力のあ る煙は容易に最上部に到達することになる. また, 火災ゾーンを 設定し, その範囲の在館者を他のゾーンに避難させる手法に関 しても, 初期消火が失敗するようなケースでは, 高温ガスが発生し 続け，熱も加わることになる. 防火防煙区画によるパッシブ対策が 高い信頼性を持って火㷋ゾーンの境界で煙伝播を抑制すること は, 実質的に困難であることを前提に避難シナリオを採用すべき であると考える. 具体的には, 火災ゾーンからの避難者の内, 身 体的に余裕のある者は階段を降下し続け, 建物からの避難を実 行すべきで, 休䕀や介助が必要な者について非火災ゾーンへの 一時退避方式を採用すべきである. 加えて, 火災ゾーンよりも上 階にある階は煙伝播リスクを考慮すべきであり, 特に建物の最上 階やエレベーターのサービス階 (停止階) の内の最上階やその周 辺階は煙伝播リスクへの配慮が必要である. また, 避難シミュレー ションを用いたケーススタディを通して順次避難アルゴリズムを提 案した研究にあっては, 避難開始のトリガーの与え方に検討の余 地がある. 本研究で調查した避難訓練においては, 館内放送( 火
災時には非常放送が用いられる)が使用されていたが, 音声アナ ウンスでは伝えるべき情報量に応じて所要時間も異なり，さらにい えば正確に意図が伝わるように内容やその伝える順番も重要とな る. 例えば, 自動火災報知設備により「火災が発生しました. 落ち 着いて避難して下さい.」と全館自動放送が流れた後に, 手動に 切り替え順次避難の指示を与えようとしても混乱をきたすことにな る. したがって, 実效性も考慮して避難シナリオを立案する必要 がある.

\section{3 リアルタイム技術の適用に関する課題}

順次避難シナリオを運用するには, 各階の避難者数を把握し た上で, 出火階を設定し, 流動計算や避難シミュレーションによる 予測によって円滑な避難が可能なシナリオを抽出することが可能 である.ここに, 予測においては, 事務所ビルの在館者は個々の 移動特性のばらつきが比較的小さいものの, 移動速度が遅い人 に群集流動が制御されることを考慮してパラメータを設定する必 要がある.ただし, 何か事が起きたときに在館者数の見積を誤れ ば, 避難状態の変化に影響を及ぼすことになる.したがって, 前 提条件のランダム性も考慮し順次避難シナリオのリダンダンシー についても評価する仕組みが求められる. その一方で, オフィス ビル等において, 勤急システムやビーコンを活用した位置情報を 捉えるシステムが普及すれば容易に前提条件を得ることが可能と なるため, ばらつきは人の行動に起因することになる.こうした人 の行動を把握しその影響を評価する手法として, セキュリティー技 術の一層の普及による防犯カメラ映像の活用が挙げられる. Fig. 5 に示したような画像解析によって人流状態を把握できれば, 適 切な避難行動を促す放送が可能となり，その結果を反映したリア ルタイムシミュレーションの実行により避難シナリオを調整する可 能性もある. 具体的には, ある階からの避難者の進入が滞ってい た場合 (2015 年調查における 14 階や 17 階), 早期避難を促す放 送を流したり，あるいはそうした避難遅れを考慮した場合の階段 内避難流動一の影響を, その後の避難シナリオの設定に反映す ることも可能である.こうしてより円滑な全館避難の実現を可能と するシステムの構築が将来期待できる.

\section{5. まとめ}

本研究では, ある高層事務所ビルで実施された順次避難計画 を採用した全館避難訓練の調查を実施した. その際適用される 避難シナリオを改善することによって, 避難流動が円滑(個別の 避難の混雑度や長時間化が抑制された状態)かつ建物全体から の避難完了時間を延長させない, より適切な避難シナリオを実際 の避難訓練に適用できたことを報告した. 2015 年の避難訓練に おいては, 第 3 フェイズで 8 階層からの同時避難により長時間の 滞留を生じたことから, 2016 年以降は 4 階層ずつ第 3 と第 4 フェ イズに分け実施した. しかしながら, 第 3 と第 4 フェイズの避難指 示の放送のタイヘングを必要以上に遅らせたため, 1 階の階段か らの避難流動が一時的に途切れたり, 流動量が低下した. 2017 年および 2018 年においては, そのタイミングを早めたことでその 避難流動が途切れたり, 流動量が一時的に低下しないように調 整することができた。 
2015 年の避難訓練では, 長時間に及ぶ滞留が発生したが, こ れは階段での合流によって流動量が半減し, 3 つの階で合流が 生じたことで流動量が $1 / 8$ に低下したことを確認し, そうした状態 が生じる時間を抑制することで避難者が長時間停止するような滞 留を抑制できることを明らかにした. そして, 階段内の過度な滞留 が一部の階から長時間階段に避難しない状況を生じさせたことや, 避難開始の指示の遅れが 1 階の階段出口からの避難流動を途 切れさせたり, また予想外の避難行動が生じたことを受けて, 同 一フェイズに割り振る階数や避難開始のタイミングを合流と滞留 時間の抑制を考慮して設定する必要があることを指摘した，その 上で, 避難シミュレーション等の予測技術と, 建物内の在館者人 数分布を把握する技術を考慮することに加え, 防犯カメラ映像を 活用することによって, 予測計算のみならず, リアルタイムで人流 状態を把握し予想外の避難行動が生じた場合の対処やその影 響を反映して順次避難を円滑化させる可能性について言及し た.

\section{謝辞}

避難訓練調査は, 実施関係者や参加者の皆様, また東京理科 大学, 早稲田大学, 東北学院大学の学生の協力の下に実施した. また, 本研究は, JSPS 科研費(課題番号:17K06722)の助成を受 けた.ここに記し謝意を表す.

なお, 本論文に関して開示すべき利益相反関連事項はない.

\section{参考文献}

1) Life Safety Code 101 (Number of means of egress), NFPA, 2002.

2)建築基準法施行令第 120 条(直通階段の設置)

3) 門倉博之, 関澤愛, 佐野友紀, 藤井皓介: 高層建築物での 順次避難における階段室内の流動状況と滞留発生に関す る研究 - 全館避難訓練時の行動実態観測に基づく分析と 考察-, 日本建築学会環境系論文集 2015;716: 849-856.

4) Tomonori Sano, Masanori Yajima, Hiroyuki Kadokura and Ai Sekizawa, Human behavior in a staircase during a total evacuation drill in a high-rise building, FIRE AND MATERIALS 2017; 41: 375-386.

5) Xuan $\mathrm{Xu}$, Weiguo Song, Staircase evacuation modeling and its comparison with an egress drill, Building and Environment 2009; 44: 1039-1046.

6) Karen E. Boyce, David A. Purser and T. Jim Shields, Experimental studies to investigate merging behaviour in a staircase, FIRE AND MATERIALS 2012; 36: 383-398.

7) NAOHIRO TAKEICHI, YOSHIYUKI YOSHIDA, TOMONORI SANO, TAKESHI KIMURA, HITOSHI WATANABE, and YOSHIFUMI OHMIYA, Characteristics of Merging Occupants in a Staircase, FIRE SAFETY SCIENCE, IAFSS 2005; 591-598.

8) Wei Liu, Dragomir Anguelov, Dumitru Erhan, Christian Szegedy, Scott Reed, Cheng-Yang Fu and Alexander C. Berg, SSD: Single Shot MultiBox Detector, European Conference on Computer Vision, 2016; 21-37.

9) Martin Abadi, Ashish Agarwal et al., TensorFlow: Large-Scale Machine Learning on Heterogeneous Distributed Systems, Preliminary White Paper, Google Research, 2015.

10) Tomonori Sano, Enrico Ronchi, Yoshikazu Minegishi, Daniel Nilsson, A pedestrian merging flow model for stair evacuation, Fire Safety Journal 2017 ; 89: 77-89.

11) LFB (London Fire Brigade): Phased evacuation of office building, 21 Feb. 1991 (Reviewed as current: 24 Nov. 2015).

12) P. Sharma, K. Dhanwantri and S. Mehta, Evacuation Patterns in High-Rise Buildings, Int. J. of Civil Eng. Research, 2014; 5:255-260.

13) Marina Gravit, Ivan Dmitriev, and Kirill Kuzenkov, Phased evacuation algorithm for high-rise buildings, MATEC Web of Conferences, 2018; 245:1-9. 